\title{
Picloram release from leafy spurge roots
}

\author{
MICHAEL V. HICKMAN, CALVIN G. MESSERSMITH, AND RODNEY G. LYM
}

\begin{abstract}
Picloram (4-amino-3,5,6-trichloro-2-pyridinecarboxylic acid) release from leafy spurge (Euphorbia esula L.) roots was not affected by application rate, root system temperature, or addition of $2,4-D$, [(2,4-dichlorophenoxy)acetic acid]. Release of ${ }^{14} \mathrm{C}$ from leafy spurge roots was detected 12 hours after ${ }^{14} \mathrm{C}$-picloram foliar application and increased linearly over a 120-hour period. Over all experiments, $72 \%$ of the recovered ${ }^{14} \mathrm{C}$ remained unabsorbed on the treated leaf and $22 \%$ remained in the leaves and stems. Less than $7 \%$ of the recovered ${ }^{14} \mathrm{C}$ was in the root zone (roots plus nutrient solution), but over $60 \%$ of this portion was in the nutrient solution. Adding 2,4-D at rates up to $1.1 \mathrm{~kg} / \mathrm{ha}$ to ${ }^{14} \mathrm{C}$-picloram at $0.14 \mathrm{~kg} / \mathrm{ha}$ did not affect ${ }^{14} \mathrm{C}$ release from leafy spurge roots. The experimentally determined temperature coefiicient $\left(Q_{10}\right)$ for ${ }^{14} \mathrm{C}$ picloram release from leafy spurge roots was $1.3 \pm 0.8$. A linear rate of picloram release with time and a $Q_{10}$ of 1.3 support the hypothesis of passive release of picloram from leafy spurge roots.
\end{abstract}

Key Words: Euphorbia esula, herbicide exudation, $Q_{10},{ }^{14} \mathrm{C}$ picloram, temperature coefficient

Leafy spurge (Euphorbia esula L.) is an introduced perennial weed that infests nearly 350,000 ha in North Dakota (Messersmith and Lym 1983) and over 1 million ha in North America (Dunn 1979). Leafy spurge is very competitive and displaces desirable forage species, resulting in reduced pasture and range productivity.

Leafy spurge is controlled most successfully with herbicides. Several herbicides are available for leafy spurge control including picloram, (4-amino-3,5,6-trichloro-2-pyridinecarboxylic acid), 2,4,-D [(2,4-dichlorophenoxy)acetic acid], dicamba (3,6-dichloro2-methoxybenzoic acid), and glyphosate [ $N$-(phosphonomethyl) glycine]. Although long-term control on grassland is best with picloram, the dose needed often is not economically feasible. Mixtures of low rates of picloram plus 2,4-D applied annually have been shown to be economical (Lym and Messersmith 1985).

The release of herbicides from plant roots following foliar application has been documented (Bybee 1979, Chang and VanderBorn 1968, Fites, et al. 1964, Weidermyer and Nalewaja 1969). Picloram was released from 'Black Valentine' bean (Phaseolus vulgaris L.) roots following foliar applications (Hurtt and Foy 1965). Bybee (1979) measured up to $7 \%$ of foliar-applied ${ }^{14} \mathrm{C}$-picloram in the nutrient solution following release by leafy spurge roots. Picloram was detected to a depth of $39 \mathrm{~cm}$ within 3 weeks after treatment in

\footnotetext{
Authors are research agronomist, USDA-Agricultural Research Service, Subtropical Agricultural Research Laboratory, Weslaco, Texas 78596, professor and associate professor, Crop and Weed Sciences Department, North Dakota State University, Fargo 58105. At the time of the research the senior author was graduate research assistant, Crop and Weed Sciences Department, North Dakota State University, Fargo.

Published with the approval of the Director, North Dakota Agricultural Experiment Station, as Journal article 1785 .

Manuscript accepted 21 December 1989.
}

the field but $86 \%$ was in the upper $13 \mathrm{~cm}$ (Hickman et al. 1989). The nature of this exudation process is not well understood. Reducing picloram release from leafy spurge roots may improve herbicide efficacy and reduce monetary and environmental costs associated with picloram use.

The ratio of the reaction rate after a $10^{\circ} \mathrm{C}$ temperature increase to the reaction rate for the original temperature is expressed as the temperature coefficient $\left(Q_{10}\right)$ (Salisbury and Ross 1978). The $Q_{10}$ may be used as an indicator of metabolic involvement in biological processes. The $\mathbf{Q}_{10}$ for most enzymatically controlled reactions is at least 2.0, while the $Q_{10}$ for diffusion or other physical reactions ranges from 1.1 to 1.4 .

This research was conducted to determine the rate of picloram release from leafy spurge roots following foliar applications, and the effect of root temperature, addition of 2,4-D, and picloram application rate on picloram release from roots. An overview of the fate of foliar-applied picloram also was developed by combining the data from several experiments that had been conducted using similar techniques.

\section{Materials and Methods}

\section{General Procedure}

A single leafy spurge biotype (79-MN-008) collected near Detroit Lakes, Minn., was used in experiments to evaluate the root release of picloram. Cuttings with a minimum of 5 axillary buds were taken from the stem tips of vegetative leafy spurge plants. The lower leaves were removed and the stems dipped in a commercial mixture of $0.2 \%$ NAA (1-naphthaleneacetic acid) rooting compound ${ }^{1}$ and were planted in a mixture of peat moss, perlite, and vermiculite. Cuttings were grown for 6 to 8 weeks in the greenhouse at about $25^{\circ} \mathrm{C}$ under natural light supplemented to maintain a photoperiod of 16 hours light and 8 hours dark.

Two days before treatment, the plants were removed from the rooting medium and the roots were washed in water. Each plant was transferred into a $450-\mathrm{ml}$ aluminum-foil-covered glass bottle containing aerated nutrient solution (Hoagland and Arnon 1950).

${ }^{14} \mathrm{C}$-picloram (specific activity $623 \mathrm{MBq} / \mathrm{mmol}$ ) dissolved in ethanol was applied with a micropipet to fully expanded leaves near the middle of the stem in 10- $\mu$ l aliquots containing the desired dose. Each application was preceded and followed by $5 \mu \mathrm{l}$ of a $0.1 \%$ $(v / v)$ nonionic surfactant ${ }^{2}$ in water. The unlabeled herbicides in the picloram rate and 2,4-D experiments were applied with a movingnozzle pot sprayer delivering $160 \mathrm{~L} / \mathrm{ha}$ at $210 \mathrm{kPa}$.

At harvest, the treated leaves were removed and surface washed

\footnotetext{
${ }^{1}$ Rootone Brand F Rooting Hormone, Rhone-Poulenc Ag. Company, Research Triangle Park, North Carolina 27709.

2Surfactant WK, trimethylnonyl polyethoxyethanol, E.I. Dupont de Nemours, Wilmington, Del. 19898.
} 
by dipping 10 times in liquid scintillation (LS) fluid " $A$ " \{[toluene and ethanol $(1: 1, \mathrm{v} / \mathrm{v})]$ plus $5 \mathrm{~g} / \mathrm{L}$ PPO (2,5-diphenyloxazole) and $0.5 \mathrm{~g} / 1$ dimethyl-POPOP [1,4-bis-2-(4-methyl-5-phenyloxazolyl) benzene] to remove the unabsorbed ${ }^{14} \mathrm{C}$-picloram. The ${ }^{14} \mathrm{C}$ activity of unabsorbed picloram was quantified by LS spectrometry. The plants were sectioned into the treated leaf, stem plus leaves above the treated leaf, stem plus leaves below the treated leaf, and root. Sections were oven dried at $60^{\circ} \mathrm{C}$, weighed, and ground in a Wiley mill (No. 10 mesh). The treated leaf and subsamples of at least $10 \%$, by weight, of other plant sections were combusted in a biological tissue oxidizer. The ${ }^{14} \mathrm{CO}_{2}$ was collected in LS fluid "B" [toluene, 2-methoxyethanol, and ethanolamine $(10: 7: 3, v / v / v)$, plus $5 \mathrm{~g} / \mathrm{L}$ PPO and $0.5 \mathrm{~g} / \mathrm{L}$ dimethyl-POPOP] and was quantified by LS spectrometry.

Nutrient solution was diluted with distilled water to a final. volume of $500 \mathrm{ml}$. Three $100-\mathrm{ml}$ samples were transferred into. 150 -ml plastic cups, frozen, and lyophilized. The cups were washed 3 times with $1.5 \mathrm{ml}$ of $60 \%$ ethanol and once with $15 \mathrm{ml}$ of LS fluid "A". The washings were combined in LS vials and ${ }^{14} \mathrm{C}$ activity was quantified by LS spectrometry.

Data for trials of each experiment were subjected to Bartlett's Chi-square test for homogeneity of variance (Gomez and Gomez 1984), and data from trials were combined where appropriate. Analysis of variance or regression analysis was performed, and treatment means compared using a protected LSD test.

\section{Exudation Rate}

An experiment was conducted to determine the rate of picloram release from roots of picloram-treated leafy spurge and to determine the effect of frequent nutrient solution changes upon the release rate. The experiment was arranged in a completely random design with 2 treatments, either no solution change for 120 hours or complete solution change at $12,24,48,72,96$, and 120 hours after ${ }^{14} \mathrm{C}$-picloram was applied. An average of $1,180 \mathrm{~Bq}{ }^{14} \mathrm{C}$-picloram plus nonionic surfactant was applied to 3 leaves to give a total dose of 3,540 Bq per plant. All solutions were collected and plants were harvested 120 hours after treatment. Seven individual plants (replications) per treatment were used and the experiment was conducted 5 times.

\section{Temperature}

An experiment was conducted to determine the effect of root temperature on release of picloram from leafy spurge roots. Plant roots were maintained at 14,19 , or $32^{\circ} \mathrm{C}$ in a water bath that surrounded the nutrient-solution-containing bottles, while the shoots remained at air temperature of about $23^{\circ} \mathrm{C}$. An average of $1,310 \mathrm{~Bq}{ }^{14} \mathrm{C}$-picloram plus surfactant solution was applied to 1 leaf of each plant. The plants were maintained under lights (16 hours light $/ 8$ hours dark, $450 \mu \mathrm{E} \bullet \mathrm{m}^{-2} \bullet \mathrm{s}^{-1}$ ) in the greenhouse and were harvested 48 hours after treatment. The experiment was conducted 5 times using 7 replications (individual plants) per treatment in trials 1 and 2, 5 replications per treatment in trials 3 and 5 , and 6 replications per treatment in trial 4.

$Q_{10}$ values were calculated for all temperature ranges (14 to 19 , 14 to 32 , and 19 to $32^{\circ} \mathrm{C}$ ) using the formula:

$$
\text { where } \begin{array}{ll}
\mathrm{Q}_{10} & =\left(\mathrm{k}_{2} / \mathrm{k}_{1}\right)^{10 / \mathrm{T}_{2}-\mathrm{T}_{1}} \\
\mathrm{k}_{1} & =\text { exudation rate at lower temperature } \\
\mathrm{k}_{2} & =\text { exudation rate at higher temperature } \\
\mathrm{T}_{1} & =\text { lower temperature } \\
\mathrm{T}_{2} & =\text { higher temperature (Salisbury and Ross 1978). }
\end{array}
$$

Previous studies indicated that exudation was a linear function over the first 120 hours after treatment so exudation rates $\left(k_{1}+k_{2}\right)$ were calculated by dividing the total ${ }^{14} \mathrm{C}$-picloram released by the time after treatment. $K$ values were calculated for each trial and used only to calculate the $Q_{10}$ for that trial.

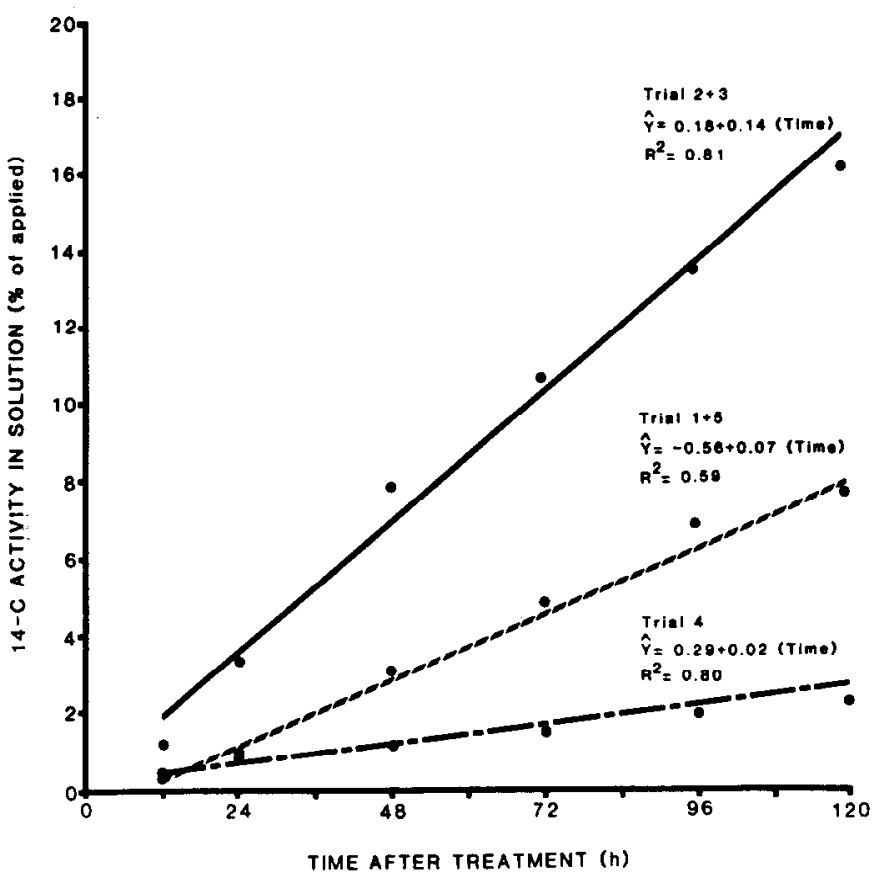

Fig. 1. ${ }^{14} \mathrm{C}$ activity released by leafy spurge roots into nutrient solution at various intervals after foliar application. Five experimental trials were conducted and trials with similar variance were combined.

\section{Picloram Rate}

An experiment was conducted to determine the effect of picloram rate on the amount of picloram released from leafy spurge roots. The plants were oversprayed with unlabeled picloram to approximate field rates of 0 ( ${ }^{4} \mathrm{C}$-picloram only), $0.02,0.04,0.07$, 0.14 , and $0.28 \mathrm{~kg} / \mathrm{ha}$, followed immediately by $1,170 \mathrm{~Bq}{ }^{14} \mathrm{C}-$ picloram plus surfactant applied to 1 leaf per plant. The bottles were covered to prevent picloram from contaminating the nutrient solutions during spraying. Plants were maintained for $\mathbf{4 8}$ hours in the greenhouse in a completely random design before harvest. The experiment consisted of 3 trials with 5 replications per treatment.

\section{Picloram Plus 2,4,-D}

An experiment was conducted to determine the effect of 2,4-D plus picloram combinations on the release of picloram from leafy spurge roots. The plants were sprayed with unlabeled picloram plus 2,4-D, followed immediately by $870 \mathrm{~Bq}{ }^{14} \mathrm{C}$-picloram plus surfactant applied to 1 leaf per plant. Spray treatments were combinations of picloram plus 2,4-D (alkanolamine salt) to give approximate field rates of 0 plus $0,0.14$ plus 0,0 plus $0.28,0.14$ plus $0.28,0.14$ plus 0.56 , and 0.14 plus $1.1 \mathrm{~kg} / \mathrm{ha}$. Bottles were covered when the herbicides were applied to prevent nutrient solution contamination. Plants were returned to the greenhouse tables in a completely random design for $\mathbf{4 8}$ hours before harvest. Four replications per treatment were used, and the experiment was conducted 3 times.

\section{Uptake and Translocation}

The variances from several similar experiments were homogeneous according to Bartlett's Chi-square test, so the data from 204 plants in 11 experimental trials were combined to produce an overview of the uptake and distribution of picloram in leafy spurge following foliar application.

\section{Results and Discussion}

\section{Exudation Rate}

The release of ${ }^{14} \mathrm{C}$-picloram from leafy spurge roots was linear with time (Fig. 1). Picloram was detected in the nutrient solution 
within 12 hours after application and the exudation generally continued at a nearly constant rate over 120 hours. Periodic changing of the nutrient solution did not affect the total amount of herbicide released into the nutrient solution or the total recovered from the leaf wash, plant or nutrient solution (data not shown).

The exudation rate was linear over time for all trials of the experiment, but large differences in the total quantity of herbicide released occurred between trials (Fig. 1). Large differences in picloram release between experimental trials reflect the high variability associated with the leafy spurge accession selected for these studies. Other researchers have found leafy spurge populations to be highly variable. Ebke and McCarty (1983) reported large variations in taxonomic factors within the leafy spurge population, not only between accessions but among stems of the same plant. Lym and Messersmith (1987) measured large variations in total nonstructural carbohydrates occurring over short time periods in an established stand of leafy spurge.

\section{Temperature}

The total ${ }^{14} \mathrm{C}$-picloram recovered was not affected by the root system temperature within trials, although the total recovery was lower in trials 2 and 4 than in trials 1,3 , and 5 (Table 1). Differences

Table 1. Recovery of ${ }^{14} \mathrm{C}$-picloram from nutrient solutions and total recovery from plants grown at root temperatures of 14,19 , and $32^{\circ} \mathrm{C}$ for 48 hours following herbicide appliention.

\begin{tabular}{|c|c|c|c|}
\hline \multirow[b]{2}{*}{ Trial $^{*}$} & \multirow[b]{2}{*}{ Temperature } & \multicolumn{2}{|c|}{${ }^{14} \mathrm{C}$-picloram recovered } \\
\hline & & Total $^{b}$ & Nutrient solution \\
\hline $\operatorname{LSD}(0.05)$ & $\begin{array}{c}1 \text { (C) } \cdots \\
14 \\
19 \\
32\end{array}$ & $\begin{array}{c}0 .(\% \\
95 \\
93 \\
97 \\
\text { NS }\end{array}$ & $\begin{array}{c}\text { applied) } \\
1.3 \\
3.5 \\
0.8 \\
2.2\end{array}$ \\
\hline $\begin{array}{l}2 \text { and } 4 \\
\text { LSD (0.05) }\end{array}$ & $\begin{array}{l}14 \\
19 \\
32\end{array}$ & $\begin{array}{l}56 \\
60 \\
63 \\
\text { NS }\end{array}$ & $\begin{array}{l}0.6 \\
1.3 \\
1.9 \\
0.9\end{array}$ \\
\hline 3 and 5 & $\begin{array}{l}14 \\
19 \\
32\end{array}$ & $\begin{array}{l}78 \\
85 \\
82 \\
\text { NS }\end{array}$ & $\begin{array}{l}0.3 \\
0.5 \\
0.7 \\
\text { NS }\end{array}$ \\
\hline
\end{tabular}

Data were combined for analysis when variances were homogeneous.

Total recovered is ${ }^{14} \mathrm{C}$ from leaf wash, plant, and nutrient solution.

in the percentage of applied ${ }^{14} \mathrm{C}$-picloram recovered from the nutrient solutions of trials 1 , and 3 and 5 did not correlate directly with the root system temperatures (Table 1). The greatest recovery in trial 1 was from plants maintained at $19^{\circ} \mathrm{C}$ while recovery for trials 2 and 4 was greater from plants maintained at $32^{\circ} \mathrm{C}$ than at $14^{\circ} \mathrm{C}$. Picloram exudation tended to be greatest from plants maintained at $32^{\circ} \mathrm{C}$ in trials 2 and 4 , and 3 and 5 . Although total recovered ${ }^{14} \mathrm{C}$-picloram was highest in trial 1 and lowest in trials 2 and 4 , exudation was not affected consistently by temperature within these trials.

$Q_{10}$ values were calculated for ${ }^{14} \mathrm{C}$-picloram exudation using all temperature differences in all trials. The $Q_{10}$ averaged $1.3 \pm 0.8$ and ranged from 0.3 to 2.3 . The average $Q_{10}$ of 1.3 , which is similar to the $\mathbf{Q}_{10}$ for diffusion of a solute in water, and the lack of a consistent effect of temperature on exudation suggests that exudation occurs passively and is not mediated by plant metabolic activity.

\section{Picloram Rate}

${ }^{14} \mathrm{C}$-picloram release, measured as a percentage of herbicide applied, was not affected by increasing picloram rates (Table 2). However, the absolute quantity of picloram released, with a constant release rate, tended to increase as the amount applied
Table 2. Recovery of ${ }^{14} \mathrm{C}$-picloram from nutrient solution and total recovery 48 hours after treatment with picloram at several rates.

\begin{tabular}{|c|c|c|c|}
\hline \multirow[b]{2}{*}{ Trial $^{*}$} & \multirow{2}{*}{$\begin{array}{l}\text { Broadcast } \\
\text { Treatment }^{b}\end{array}$} & \multicolumn{2}{|c|}{${ }^{14} \mathrm{C}$-picloram recovered } \\
\hline & & Total $^{c}$ & Nutrient solution \\
\hline & \multicolumn{3}{|c|}{$\cdots-(\mathrm{kg} / \mathrm{ha})-\cdots \cdots$} \\
\hline 1 and 2 & $\begin{array}{c}0 \\
0.02 \\
0.04 \\
0.07 \\
0.14 \\
0.28\end{array}$ & $\begin{array}{l}61 \\
64 \\
65 \\
72 \\
78 \\
81 \\
\text { NS }\end{array}$ & $\begin{array}{r}3.4 \\
2.7 \\
4.8 \\
3.4 \\
4.9 \\
6.3 \\
\text { NS }\end{array}$ \\
\hline LSD (0.05) & $\begin{array}{c}0 \\
0.02 \\
0.04 \\
0.07 \\
0.14 \\
0.28\end{array}$ & $\begin{array}{l}85 \\
67 \\
85 \\
78 \\
86 \\
96 \\
\text { NS }\end{array}$ & $\begin{array}{r}4.0 \\
6.4 \\
11.2 \\
5.5 \\
8.1 \\
11.9 \\
\text { NS }\end{array}$ \\
\hline
\end{tabular}

Data were combined for analysis when variances were homogeneous.

${ }^{b}{ }^{4} \mathrm{C}$-picloram was applied to a single fully expanded leaf immediately following broadcast application of picloram to provide the desired rate.

Total recovery is ${ }^{14} \mathrm{C}$ from leaf wash, plant, and nutrient solutions.

increased. In field studies picloram release was correlated with application rate averaging 490,820 , and $1,420 \mathrm{pbbw}$ in the soil when applied at 30,60, and $120 \mathrm{~g} / \mathrm{L}$, respectively (Hickman et al. 1989).

A hypothesis of passive release through diffusion suggests that increasing the amount of picloram applied would result in a linear increase in the total quantity of picloram released, but a constant rate of release when expressed as a percentage of herbicide applied. At picloram concentrations below the saturation level for active carriers, active and passive exudation systems would be indistinguishable. Results of the picloram rate trials and a $Q_{10}$ of 1.3, support a hypothesis of passive picloram release from leafy spurge roots.

\section{Picloram Plus 2,4-D}

Combinations of picloram plus 2,4-D have been synergistic for leafy spurge control which is at least partly due to more unmetabolized ${ }^{14} \mathrm{C}$ translocated to the roots when applied with ${ }^{14} \mathrm{C}-2,4-\mathrm{D}$ than when applied alone (Lym and Moxness 1989).

${ }^{14} \mathrm{C}$-picloram recovered from nutrient solutions was similar for plants treated with picloram alone and with picloram + 2,4-D (Table 3). This suggests that the synergistic action of picloram plus 2,4-D on leafy spurge is not due to reduced release of picloram from roots. The synergistic response of picloram plus 2,4-D for leafy spurge control could be due to an effect of picloram on 2,4-D leakage, but these experiments were not designed to test this hypothesis.

\section{Uptake and Translocation}

An average of $75 \%$ of the ${ }^{14} \mathrm{C}$-picloram applied was recovered from the 204 treated leafy spurge plants and the recovery ranged from 63 to $97 \%$ (Table 4). The leaf wash accounted for $54 \%$ of the applied or $72 \%$ of the recovered ${ }^{14} \mathrm{C}$. Picloram removed by the washing procedure remained either on the leaf surface or in the cuticle and would be of minimal value for weed control. Picloram is subject to photolytic degradation (Hall et al. 1968) and that remaining on the leaf surface could be readily degraded by sunlight.

Absorbed picloram is translocated primarily in the symplast although some apoplastic transport also occurs (Sharma et al. 1971, Sharma and Vanden Born 1970 and 1973). The distribution of ${ }^{14} \mathrm{C}$ in leafy spurge is consistent with symplastic movement in 
Table 3. Recovery of ${ }^{14} \mathrm{C}$-picloram from nutrient solutions and total recovery 48 hours after broadcast treatment with picloram plus 2,4D at several rates.

\begin{tabular}{|c|c|c|c|}
\hline \multirow[b]{2}{*}{ Trial" } & \multirow[b]{2}{*}{ Picloram + 2,4-D } & \multicolumn{2}{|c|}{${ }^{14} \mathrm{C}$-picloram recovered } \\
\hline & & Total $^{\mathrm{c}}$ & Nutrient solution \\
\hline $\operatorname{LSD}(0.05)$ & $\begin{array}{c}-(\mathrm{kg} / \mathrm{ha}) \cdots \\
0+0 \\
0.14+0 \\
0+0 \\
0.14+0.28 \\
0.14+0.56 \\
0.14+1.12\end{array}$ & $\begin{array}{c}-1 \% \\
88 \\
77 \\
77 \\
80 \\
80 \\
78 \\
8\end{array}$ & $\begin{array}{c}\text { pplied) } \\
5.8 \\
4.8 \\
6.2 \\
5.3 \\
3.5 \\
2.3 \\
\text { NS }\end{array}$ \\
\hline $\operatorname{LSD}(0.05)$ & $\begin{array}{c}0+0 \\
0.14+0 \\
0+0.28 \\
0.14+0.28 \\
0.14+0.56 \\
0.14+1.12\end{array}$ & $\begin{array}{c}82 \\
74 \\
86 \\
85 \\
88 \\
86 \\
\text { NS }\end{array}$ & $\begin{array}{l}1.5 \\
1.2 \\
1.4 \\
0.8 \\
1.0 \\
1.6 \\
\text { NS }\end{array}$ \\
\hline
\end{tabular}

Data were combined for analysis when variances were homogeneous.

${ }_{1}{ }^{4} \mathrm{C}$-picloram was applied to a single fully expanded leaf immediately following broadcast application of picloram plus 2,4-D.

${ }^{\circ}$ Total recovery is ${ }^{14} \mathrm{C}$ from leaf wash, plant, and nutrient solution.

vegetative plants since most of the herbicide moved to the actively growing stem and leaf tissues above the treated leaf (data not shown). The leaves and stems of the treated plants contained $16 \%$ of the applied herbicide, which accounted for nearly $22 \%$ of the ${ }^{14} \mathrm{C}$ recovered (Table 4 ). The treated leaf contained over $38 \%$ of the ${ }^{14} \mathrm{C}$ that was recovered from the topgrowth.

Control of leafy spurge and other perennial weeds depends upon killing of the root system. Less than $7 \%$ of the herbicide recovered was detected in the root zone of leafy spurge, and over $60 \%$ of this portion was recovered in the nutrient solution (Table 4). Picloram did not translocate readily from topgrowth into leafy spurge roots. Similarly, Lingle and Suttle (1985) found that only 10 to $30 \%$ of the 2,4-D applied to leafy spurge leaves was translocated into the root zone and $80 \%$ of that was released from the roots into the nutrient solution.

Table 4. ${ }^{14} \mathrm{C}$ recovery from plant tissue and nutrient solution following folitir application of ${ }^{14} \mathrm{C}$-picloram plus surfactant.

\begin{tabular}{|c|c|c|c|}
\hline \multirow[b]{2}{*}{ Location } & \multicolumn{2}{|c|}{${ }^{14} \mathrm{C}$ recovery } & \multirow[b]{2}{*}{ Mean } \\
\hline & Mean \pm SD & Range $^{b}$ & \\
\hline & \multicolumn{2}{|c|}{$\ldots-(\%$ of applied $) \ldots$} & (\% of recovered) \\
\hline Leaf wash & $54 \pm 10$ & $39-69$ & 72 \\
\hline Stem & & & \\
\hline $\begin{array}{l}\text { Treated leaf } \\
\text { Other leaves and }\end{array}$ & $6 \pm 2.4$ & $3.1-10.2$ & 8 \\
\hline $\begin{array}{l}\text { stems } \\
\text { Stem total }\end{array}$ & $\begin{array}{l}10 \pm 6.6 \\
16\end{array}$ & $2.7-25.0$ & $\begin{array}{l}13 \\
21\end{array}$ \\
\hline Root zone & & & \\
\hline $\begin{array}{l}\text { Roots } \\
\text { Nutrient solution } \\
\text { Root zone total }\end{array}$ & $\begin{array}{l}2.0 \pm 1.2 \\
3.0 \pm 4.3 \\
5.0\end{array}$ & $\begin{array}{l}0.3-3.8 \\
0.5-19.3\end{array}$ & $\begin{array}{l}3 \\
4 \\
7\end{array}$ \\
\hline Total recovery & $75 \pm 10$ & $63-97$ & 100 \\
\hline
\end{tabular}

${ }^{-14} \mathrm{C}$ recovery based on an average ${ }^{14} \mathrm{C}$-picloram application of $1,250 \mathrm{~Bq}$ on 204 plants of 11 experimental trials.

\section{Summary}

The mechanism of picloram release is not known. Lack of change in picloram release due to increasing temperature and herbicide rate, compiled with a $Q_{10}$ value of 1.3 , suggest that picloram release by leafy spurge is a passive process. Therefore, increased picloram efficiency for leafy spurge control must come from increasing the amount of picloram translocated into plant roots.

Spray additives that enhance picloram uptake by increasing cuticular penetration or by prolonging the drying time may improve leafy spurge control. Increased absorption in response to surfactant additives has been reported in several perennial weeds (Sharma et al. 1971, Sharma and Vanden Born 1970, Wilson and Nishimoto 1975). Timing of spraying applications to take advantage of periods of highest relative humidity to improve picloram absorption (Moxness and Lym 1989) or optimum plant growth stage to reduce exudation (Hickman et al. 1989) also may be advantageous.

\section{Literature Cited}

Bybee, T.A. 1979. Factors affecting leafy spurge control including leafy spurge reestablishment, herbicide application dates, herbicide translocation and root carbohydrates. Ph.D. Thesis, North Dakota State Univ., Fargo.

Chang, F.Y., and W.H. Vanden Born. 1968. Translocation of dicamba in Canada thistle. Weed Sci. 16:176-181.

Dunn, P.H. 1979. The distribution of leafy spurge (Euphorbia esula) and other weedy Euphorbia spp. in the United States. Weed Sci. 27:509-516.

Ebke, D.H., and M.K. McCarty. 1983. A nursery of leafy spurge (Euphorbia spp.) complex from North America. Weed Sci. 31:866-873.

Fites, R.C., F.W.Slife, and J.B. Hanson. 1964. Translocation and metabolism of radioactive 2,4-D in jimsonweed. Weeds 12:180-183.

Gomez, K.A., and A.A. Gomez. 1984. Statistical procedures for agricultural research, 2nd edition. John Wiley and Sons, Inc., New York. 679 p.

Hall, R.C., C.S. Giam, and M.G. Merkle. 1968. The photolytic degradation of picloram. Weed Res. 8:292-297.

Hickman, M.V., C.G. Messersmith, and R.G. Lym. 1989. Picloram release from leafy spurge (Euphorbia esula) roots in the field. Weed Sci. 37:167-174.

Hosglund, D.R., and D.I. Armon. 1950. The water culture method for growing plants without soil. Calif. Agr. Exp. Sta. Circ. 347:1-32.

Hurtt, W., and C.L. Foy. 1965. Excretion of foliar-applied dicamba and picloram from roots of Black Valentine beans grown in soil, sand, and culturc solution. Proc. Northeast. Weed Control Conf. 19:602.

Lingle, S.E., and J.C. Suttle. 1985. A model system for the study of 2,4-D translocation in leafy spurge. Can. J. Plant Sci. 65:369-377.

Lym, R.G., and C.G. Messersmith. 1985. Leafy spurge control with herbicides in North Dakota: 20-year summary. J. Range Manage. 38:149-154.

Lym, R.G., and C.G. Messersmith. 1987. Carbohydrates in leafy spurge roots as influenced by environment. J. Range Manage. 40:139-144.

Lym, R.G., and K.D. Moxness. 1989. Absorption, translocation, and metabolism of picloram and 2,4-D in leafy spurge (Euphorbia esula). Weed Sci. 37:498-502.

Messersmith, C.G., and R.G. Lym. 1983. Distribution and economic impacts of leafy spurge in North Dakota. North Dakota Farm Res. 40(5):8-13.

Moxness, K.D., and R.G. Lym. 1989. Environment and spray additive effects on picloram absorption and translocation in leafy spurge (Euphorbia esula). Weed Sci. 37:181-186.

Neidermyer, R.W., and J.D. Nalewaja. 1969. Uptake, translocation and fate of 2,4-D in nightflowering catchfly and common lambsquarters. Weed Sci. 17:528-532.

Salisbury, F.B., and C. Ross. 1978. Plant physiology, 2nd ed. Wadsworth Publishing Co., Belmont, Calif.

Sharma, M.P., E.Y. Chang, and W.H. Vanden Born. 1971. Penetration and translocation of picloram in Canada thistle. Weed Sci. 19:349-355.

Sharma, M.P., and W.H. Vanden Born. 1970. Foliar penetration of picloram and 2,4-D in aspen and balsam poplar. Weed Sci. 18:57-63.

Sharma, M.P., and W.H. Vanden Born. 1973. Fate of picloram in Canada thistle, soybean, and barley. Weed Sci. 21:350-353.

Wilson, B.J., and R.K. Nishimoto. 1975. Ammonium sulfate enhancement of picloram activity and absorption. Weed Sci. 23:289-296. 